\title{
Exogenous enzyme complex prevents intestinal soybean meal- induced enteritis in Mugil liza (Valenciennes, 1836) juvenile
}

\author{
LEONARDO R.V. RAMOS ${ }^{1}$, VIRGÍNIA F. PEDROSA ${ }^{1}$, AGNES MORI ${ }^{2}$, CARLOS F.F. DE \\ ANDRADE ${ }^{1}$, LUIS A. ROMANO ${ }^{1}$, PAULO C. ABREU ${ }^{1}$ and MARCELO B. TESSER ${ }^{1}$ \\ ${ }^{1}$ Programa de Pós-Graduação em Aquicultura, Universidade Federal do Rio Grande/FURG, \\ Avenida Itália, Km 8, s/n, Bairro Carreiros, 96201-900 Rio Grande, RS, Brazil \\ ${ }^{2}$ Adisseo Brasil Nutrição Animal, Avenida Maria Coelho Aguiar, 215, Bloco G, \\ $1^{\circ}$ andar, Jardim São Luis, 05804-900 São Paulo, SP, Brazil
}

Manuscript received on July 12, 2016; accepted for publication on September 20, 2016

\begin{abstract}
Four soybean meal-based diets containing increasing levels of an enzyme complex (E50, E100, E150 and E200 at 50, 100, 150 and $200 \mathrm{~g} \mathrm{ton}^{-1}$, respectively) and one soybean meal-based diet without the enzyme complex (E0) were fed in triplicate to $M$. liza juveniles in a semi-static flow system with 20 fish per tank for 75 days. There were no differences between the treatments for animal performance parameters, but fish fed the enzyme complex treatment exhibited significantly $(P<0.05)$ higher values of calcium bone retention compared with control fish. Although there was no relationship between bacterial counts in different sections of the gastrointestinal tract or enzyme levels, filamentous bacteria were increased in E50 compared with E150. All of the treatments resulted in higher bacterial counts in the stomach than in intestinal segments. Histological screening showed serious to moderate infiltration of inflammatory cells, modification in villus morphology and necrosis in some cases in fish fed the E0 diet. In addition, fish from the E0 treatment exhibited significantly $(P<0.05)$ lower lipid deposition in the peritoneal cavity. Therefore, the use of low levels of exogenous enzyme is recommended in diets for M. liza when soybean meal is used as the main source of protein.
\end{abstract}

Key words: Carbohydrase, growth, histology, microorganisms, mullet, phytase.

\section{INTRODUCTION}

Replacing fish meal with plant feedstuffs in aquafeed has been identified as an essential requirement for the future development of aquaculture. However, most of the potential plant-derived nutrient sources contain a variety of antinutritional substances, such phytic acid and non-starch polysaccharides, that may reduce the feed intake, growth, nutrient

Correspondence to: Leonardo Rocha Vidal Ramos

E-mail: rochavr.leo@gmail.com digestibility and affect the function of internal organs and weaken disease resistance (Francis et al. 2001, Hardy 2010, Krogdahl et al. 2010). To achieve acceptable growth rates, fish diets should be supplemented with plant-derived protein sources, including amino acids, flavorings and exogenous enzymes (Gatlin et al. 2007). In poultry and swine production, such outcomes are minimized or avoided by the enzyme inclusion in their plantbased diets; but the moiety of exogenous enzyme supplementation in fish diets still in infancy and 
based in non-ruminant recommendations (Castillo and Gatlin 2014), which yields contradictory results.

As reviewed by Barletta (2010), the use of enzymes arose during the 1980s in poultry nutrition in Europe, where wheat and barley were the main feeds used in diet formulation. The introduction of fiber-degrading or carbohydrase enzymes improved bird production and lowered feed costs. Significant improvements were then achieved with the inclusion of phytase. However, phosphorus pollution increases in the excrement from non-ruminant animals fed vegetable source. Thus the application of phytase enzymes has been examined due to their impact on the environment and animal growth performance (Singh and Satyanarayana 2014).

Few studies evaluate enzyme supplementation in feed for aquatic organisms, and many dietary recommendations for aquatic organisms are based on results obtained for non-ruminants animals (Castillo and Gatlin 2014). Enzyme usage for fish has yielded contradictory results, largely due to over-reliance on the type of vegetable source used, enzymatic profile and inclusion level added to the diets, as well as fish species used in the studies. In this sense, studies have been conducted to evaluate different enzymes, and different inclusion levels between feed sources. Increases in fish performance have been observed, such as those for species including Atlantic salmon Salmo salar, Japanese seabass Lateolabrax japonicas, rainbow trout Oncorhynchus mykiss, hybrid tilapia Oreochromis niloticus x O. aureus, African catfish Clarias garipienus, great sturgeon Huso huso and grass carp Ctenopharyngodon idella (Carter et al. 1994, Ai et al. 2007, Lin et al. 2007, Yildirim and Turan 2010, Ghomi et al. 2012, Zhou et al. 2013, Zamini et al. 2014).

The mullet Mugil liza is a recommended species for aquaculture, due the fact that it is detritivore species (Oliveira and Soares 1996), exhibits resilience to a wide temperature and salinity range, and is easily fed (Miranda-Filho et al. 2010). According to González Castro et al (2009), this species is fast growing in their natural environment when compare with other species of mullets, such as $M$. cephalus, the world's mostproduced Mugilidae species (FAO 2006). However, studies regarding the nutritional requirements of $M$. liza are scarce. Carvalho et al. (2010) determined the optimum level of crude protein for M. liza as $35 \mathrm{~g} \mathrm{~kg}^{-1}$. Zamora-Sillero et al. (2013) studied dextrin inclusion in the feed, determining that juvenile mullets could be fed with diets containing up to $35 \mathrm{~g} \mathrm{~kg}^{-1}$ dextrin. More recently, Ramos et al. (2015a, b) evaluated the inclusion of soluble non-starch polysaccharides, observing no effect on fish performance when fed diets with citrus pectin, while the inclusion of guar gum resulted in a decrease in performance with higher inclusion levels (8 and $12 \mathrm{~g} \mathrm{~kg}^{-1}$ ).

Therefore, the aim of this study was to evaluate the effect of increasing levels of an exogenous enzyme complex in a soybean meal based-diet for $M$. liza. Growth performance, muscle composition, bone calcium and phosphorus retention, gastrointestinal tract histology and gastrointestinal microbial profiles were analyzed.

\section{MATERIALS AND METHODS}

\section{FISH CAPTURE AND CONDITIONING}

All of the procedures and protocols were performed in accordance with the guidelines for animal use and were approved by the Animal Ethic Committee of the Federal University of Rio Grande - FURG (CEUA, protocol number Pq008\2014).

Juvenile mullet individuals were caught at Casino Beach (Rio Grande - RS, Brazil; 32¹7'S$\left.52^{\circ} 10^{\prime} \mathrm{W}\right)$ using a seine net $(2.5 \mathrm{~m} \times 1.5 \mathrm{~m}$; mesh size $5.0 \mathrm{~mm}$ ) and taken to the Laboratório de Piscicultura Estuarina e Marinha of the Federal University of Rio Grande. The animals were stocked in one circular 300-L tank at a density 
of one fish per liter before the beginning of the experiment for feed training purposes (hand-fed four times per day) for one week.

\section{WATER PARAMETERS}

The water parameters were monitored daily. The dissolved oxygen content and temperature were measured using an oxygen meter (YSI 50A, Yellow Springs, OH, USA). The $\mathrm{pH}$ was determined using a digital $\mathrm{pH}$ meter $\left(\mathrm{YSI}^{\circledR}{ }^{\circledR}\right.$-pH100, Yellow Springs, OH, USA), and salinity was estimated using a handheld refractometer (Atago ${ }^{\circledR}$, model 103, Tokyo, Japan). Ammonia and alkalinity were measured every other day via the UNESCO (1983) method. The average value for water temperature was $24.0 \pm 0.09^{\circ} \mathrm{C}$, salinity $20.2 \pm 0.98 \mathrm{~g} \mathrm{~L}^{-1}$, dissolved oxygen $7.05 \pm 0.27 \mathrm{mg} \mathrm{L}^{-1}$, total ammonium nitrogen $0.61 \pm 0.13 \mathrm{mg} \mathrm{L}^{-1}$ and alkalinity $104.24 \pm$ $14.34 \mathrm{mg} \mathrm{CaCO} \mathrm{L}{ }^{-1}$.

\section{EXPERIMENTAL DIETS}

The experimental diets consisted of a control soybean meal based-diet (Table I), without the inclusion of the enzyme complex (E0) and four others soybean meal based-diets supplemented with different levels of the enzyme cocktail (E50: $50 \mathrm{~g}_{\text {ton }}{ }^{-1}$; E100: $100 \mathrm{~g} \mathrm{ton}^{-1}$, E150: $150 \mathrm{~g} \mathrm{ton}^{-1}$ and E200: $200 \mathrm{~g} \mathrm{ton}^{-1}$ ). The enzyme levels were chosen based in the literature review information available in the Castillo and Gatlin (2014). The control diet was formulated to meet the nutritional requirements of mullet (Carvalho et al. 2010), with soybean meal representing the major source of protein of the diets $\left(21.4 \mathrm{~g} \mathrm{~kg}^{-1}\right)$ followed by wheat gluten $\left(6.46 \mathrm{~g} \mathrm{~kg}^{-1}\right)$ and fish meal $(1.37 \mathrm{~g}$ $\left.\mathrm{kg}^{-1}\right)$. Other plant ingredients, such as rice meal and wheat meal contribute with 2.26 and $3.23 \mathrm{~g} \mathrm{~kg}^{-1}$ of crude protein, respectively. Enzymatic cocktail was supplied by Adisseo, Animal Nutrition, Brazil. The enzymatic activities of the diets were measured at Centre d'Analyse, de Recherche et d'Appui Technique (Adisseo, Commentry, France) (Table I).
The enzyme complex was composed of non-starch polysaccharidases, including xylanases (endo-1,4 $\beta$-xylanase, $\alpha$-arabinofuranosidase, $\beta$-xylosidase, feruloyl esterase, endo-1,5 $\alpha$-arabinase), $\beta$-glucanases (endo-1,3(4) $\beta$-glucanase, $\beta$ - 1,3 glucanase [laminarinase] endo-1,4 $\beta$-glucanase [cellulase], cellobiohydrolase, $\beta$-glucosidase), pectinases (pectinase, polygalacturonase, pectinesterase, rhamnogalacturonase) mannanases (endo-1,4 $\beta$-mannanase); phytase (6-phytase); and others enzymes ( $\alpha$-galactosidase, aspartate protease, metalloprotease). For feed processing, the dry ingredients were homogenized, and oil was added further. The enzyme complex was dissolved in distilled water and further added to the premix dry ingredients until obtain a consistent texture that allowed the feed to be pelleted in a meat grinder using a 2-mm-diameter die. The E0 diet was processed following the same procedure, however, without enzyme addition. The processing temperature was maintained below $60^{\circ} \mathrm{C}$ to avoid the enzyme denaturation. Subsequently, the pellets were dried in a forced-circulation oven for $6 \mathrm{~h}$ at $55^{\circ} \mathrm{C}$ and stored in sealed plastic bags in a freezer at $-20^{\circ} \mathrm{C}$ until use.

\section{GROWTH TRIAL}

An experimental design of five treatments with three replicates each was used in this study. After the conditioning period, the fish were anesthetized with benzocaine (50 ppm), subjected to an initial weighing $(0.18 \pm 0.005 \mathrm{~g})$ and distributed in a semi-static system of 1550 -L rectangular tanks at a density of 20 fish per tank. The fish were handfed four times per day (9:00 AM, 12:00 AM, 15:00 PM, 18:00 PM) until apparent satiation. At the end of each day, the remaining diets were weighed using a precision analytical scale $( \pm 0.01 \mathrm{~g}, \mathrm{BL}-$ 3200 H, Marte, São Paulo, SP, Brazil) to record the daily feed intake. After the first feeding, the tanks were cleaned and filled with treated seawater (chlorinated, filtered through a $5 \mu \mathrm{m}$ bag filter and 
TABLE I

Feed ingredients and proximate composition of the soybean-based diet and feed enzyme activity of the experimental diets.

\begin{tabular}{|c|c|c|c|c|c|c|}
\hline \multicolumn{3}{|c|}{ Feed ingredients } & \multicolumn{4}{|c|}{ Dry matter $\left(\mathrm{g} \mathrm{kg}^{-1}\right)$} \\
\hline \multicolumn{3}{|c|}{ Fish meal } & \multicolumn{4}{|c|}{20.0} \\
\hline \multicolumn{3}{|l|}{ Soybean meal } & \multicolumn{4}{|c|}{460.0} \\
\hline \multicolumn{3}{|l|}{ Wheat gluten } & \multicolumn{4}{|c|}{80.0} \\
\hline \multicolumn{3}{|l|}{ Rice meal } & \multicolumn{4}{|c|}{200.0} \\
\hline \multicolumn{3}{|l|}{ Wheat meal } & \multicolumn{4}{|c|}{200.0} \\
\hline \multicolumn{3}{|l|}{ Fish oil } & \multicolumn{4}{|c|}{30.0} \\
\hline \multicolumn{2}{|l|}{ Premix } & & \multicolumn{4}{|c|}{10.0} \\
\hline \multicolumn{7}{|c|}{ Proximal composition } \\
\hline \multicolumn{3}{|l|}{ Dry matter } & \multicolumn{4}{|c|}{975.3} \\
\hline \multicolumn{3}{|l|}{ Crude protein } & \multicolumn{4}{|c|}{360.7} \\
\hline \multicolumn{3}{|l|}{ Ether extract } & \multicolumn{4}{|c|}{85.3} \\
\hline \multicolumn{3}{|l|}{ Ash } & \multicolumn{4}{|c|}{58.5} \\
\hline \multicolumn{3}{|l|}{ Crude fiber } & \multicolumn{4}{|c|}{52.1} \\
\hline \multicolumn{3}{|c|}{ Non-nitrogenous extract } & \multicolumn{4}{|c|}{443.4} \\
\hline \multicolumn{3}{|c|}{ Metabolizable energy $\left(\mathrm{MJ} \mathrm{g}^{-1}\right)^{2}$} & \multicolumn{4}{|c|}{16.45} \\
\hline \multicolumn{3}{|c|}{ Phosphorus (\%) } & \multicolumn{4}{|c|}{10.55} \\
\hline Calcium $(\%)$ & & & & & & \\
\hline & & Enzymatic & tivity & & & \\
\hline Experimental & Phyt & activity & & Inase activity & $\begin{array}{r}\mathrm{Ca} \\
\text { phosp }\end{array}$ & $\begin{array}{l}\text { and } \\
\text { content }\end{array}$ \\
\hline & Target & FTU kg ${ }^{-1}$ & Target & Visco units $\mathrm{kg}^{-1}$ & $\% \mathrm{Ca}$ & $\% \mathrm{P}$ \\
\hline E50 & 500 & 814 & 1100 & 904 & 1.17 & 10.54 \\
\hline E100 & 1000 & 1256 & 2200 & 2198 & 1.31 & 10.28 \\
\hline E150 & 1500 & 1402 & 3300 & 2821 & 1.37 & 11.08 \\
\hline E200 & 2000 & 1696 & 4400 & 3927 & 1.40 & 11.45 \\
\hline
\end{tabular}

E50: $50 \mathrm{~g} \mathrm{ton}^{-1}$, E100: $100 \mathrm{~g}_{\text {ton }}{ }^{-1}$, E150: $150 \mathrm{~g} \mathrm{ton}^{-1}$, E200: $200 \mathrm{~g} \mathrm{ton}^{-1}$. ${ }^{1}$ Premix M. Cassab, SP, Brazil: Vit. A (500,000 UI kg $\left.{ }^{-1}\right)$, Vit. D3 $\left(250,000 \mathrm{UI} \mathrm{kg}^{-1}\right)$, Vit. E $\left(5,000 \mathrm{mg} \mathrm{kg}^{-1}\right)$, Vit. K $\left(500 \mathrm{mg} \mathrm{kg}^{-1}\right)$, Vit. B1 $(1,000$ $\left.\mathrm{mg} \mathrm{kg}{ }^{-1}\right)$, Vit. B2 (1,000 mg kg-1 $)$, Vit. B6 (1,000 $\left.\mathrm{mg} \mathrm{kg}^{-1}\right)$ Vit. B12 (2,000 $\left.\mathrm{mcg} \mathrm{kg}^{-1}\right)$, Niacin $\left(2,500 \mathrm{mg} \mathrm{kg}^{-1}\right)$, Calcium pantothenate $\left(4,000 \mathrm{mg} \mathrm{kg}^{-1}\right)$, folic acid $\left(500 \mathrm{mg} \mathrm{kg}^{-1}\right)$, biotin $\left(10 \mathrm{mg} \mathrm{kg}^{-1}\right)$, vit. C $\left(10,000 \mathrm{mg} \mathrm{kg}^{-1}\right)$. Colin $\left(100,000 \mathrm{mg} \mathrm{kg}^{-1}\right)$, Inositol $\left(1,000 \mathrm{mg} \mathrm{kg}^{-1}\right)$. Trace elements: selenium $\left(30 \mathrm{mg} \mathrm{kg}^{-1}\right)$, iron $(5,000 \mathrm{mg}$ $\left.\mathrm{kg}^{-1}\right)$, copper $\left(5,000 \mathrm{mg} \mathrm{kg}^{-1}\right)$, manganese $\left(5,000 \mathrm{mg} \mathrm{kg}^{-1}\right)$, zinc $\left(9,000 \mathrm{mg} \mathrm{kg}^{-1}\right)$, cobalt $\left(50 \mathrm{mg} \mathrm{kg}^{-1}\right)$, iodine $\left(200 \mathrm{mg} \mathrm{kg}^{-1}\right) .{ }^{2}$ Calculated from physiological standard values, where $1 \mathrm{~kg}$ of carbohydrate (N-free extract), protein and lipid yields 16.7, 16.7 and 37.6 MJ, respectively (Garling and Wilson 1976).

passed through ultraviolet light) daily; sodium thiosulfate was used to neutralize the chlorine before utilization. The environmental conditions were maintained at $25^{\circ} \mathrm{C}$ with room air conditioning, salinity of 30 and a photoperiod of 14L:10D until the end of the experimental period (75 days).

At the end of the experiment, all fish were weighed and measured to obtain the following growth parameters and biometrical indices:

- Weight gain (g): final weight - initial weight;
- Specific growth rate $\left(\% \mathrm{dia}^{-1}\right)$ : (ln final weight $-\ln$ initial weight)/days farming $\mathrm{x}$ 100 ;

- Feed intake (\%): (mean dry fed feed daily x mean fish mass) x 100

- Apparent feed conversion rate: diet supplied/ weight gain;

- Protein efficiency ratio: weight gain/protein intake;

- Condition factor $(k)$ : (live weight/corporal length $\left.{ }^{3}\right) \times 100$; 
- Survival: ((initial number of fish - number of dead fish) / initial number of fish)*100

- Calcium retention (\%): [(final weight $\mathrm{x}$ final bone calcium) - (initial weight $\mathrm{x}$ initial bone calcium)/total dry calcium intake] x 100;

- Phosphorus retention (\%): [(final weight $\mathrm{x}$ final bone phosphorus) - (initial weight $\mathrm{x}$ initial bone phosphorus)/total dry phosphorus intake] x 100;

- Hepatosomatic index (\%): (liver weight/ total body weight) $\mathrm{x} 100$; and

- Viscerosomatic index (\%): (viscera weight/ total body weight) $\mathrm{x} 100$.

The hepatosomatic index, viscerosomatic index, carcass composition, calcium and phosphorus bone content, histological analysis and bacterial counts were obtained using fish that had been euthanized with an overdose of benzocaine (300 ppm). The liver and gastrointestinal tract were removed from all of the fish, weighed and separated. The carcass backbones were collected to access the calcium and phosphorus bone retention and were then frozen at $-20^{\circ} \mathrm{C}$.

For gastrointestinal tract bacterial counts, the external surfaces of three fish per tank (nine per treatment) were cleaned with povidone iodine to avoid any external contaminants, the gastrointestinal tract was then excised and fixed in $4 \%$ buffered formalin. The same procedure was performed at the beginning of the experiment with ten fish. The viscera of another three fish per tank (nine per treatment) were removed, fixed for $24 \mathrm{~h}$ in Bouin's fluid and then preserved in $70 \%$ ethanol for histological analysis.

\section{ANALYTICAL METHODS}

The proximal analysis of feed and muscle was performed according to AOAC (1999) methods. Dry matter was assessed after drying the samples in an oven for $5 \mathrm{~h}$ at $102^{\circ} \mathrm{C}$. Ash was produced by burning the dry samples in a muffle furnace for $5 \mathrm{~h}$ at $600^{\circ} \mathrm{C}$. The Kjeldahl method was used for crude protein determination. The samples were digested followed by nitrogen distillation, and the results were then multiplied by 6.25 . For lipid determination, the samples were extracted using a Soxhlet extractor (TE-188/6, Tecnal, Piracicaba, SP, Brazil) for $6 \mathrm{~h}$ with petroleum ether as the solvent. The determination of calcium, phosphorus and crude fiber followed the methodology described by Silva and Queiroz (2009). The non-nitrogen extract was calculated as the value after subtracting the total crude protein, ash, ether extract and crude fiber values.

For the phosphorus and calcium analysis, the backbones were dried at $105^{\circ} \mathrm{C}$ for $5 \mathrm{~h}$ in an oven and then macerated. The samples were then defatted for $6 \mathrm{~h}$ in a Soxhlet extractor using petroleum ether as the solvent. The samples underwent acid digestion with nitric and perchloric acids; the resulting solutions were diluted in distilled water and filtered through paper filters following the methodology of Silva and Queiroz (2009). The samples were evaluated an atomic absorption spectrophotometer (GC AA 7000, GBC Scientific, Melbourne, Vic, Australia) at the a wavelength of $422.7 \mathrm{~nm}$ for the calcium analysis and using a digital spectrophotometer (B342II, Micronal, São Paulo, SP, Brazil) at a wavelength of $725 \mathrm{~nm}$ for the phosphorus analysis. The phosphorus and calcium analyses were conducted at the Laboratório de Hidroquímica/IO - FURG.

The viscera samples conserved in $70 \%$ ethanol were analyzed at the Laboratório de Imunologia e Patologia de Organismos Aquáticos - FURG; the samples were processed in a LUPE PT 05 automatic processor embedded in Paraplast ${ }^{\circledR}$ and cut into 5 - $\mu \mathrm{m}$-thick sections using a LUPETEC MRPO3 microtome. The sections were stained with hematoxylin-eosin (HE). The intestinal tissue damage was measured by applying a modified quantitative score adapted from Bakke-McKellep et al. (2007) using the pathological description of Baeverfjord and Krogdhal (1996), as follows: 
I, light lymphocyte infiltration; II, moderate lymphocyte infiltration with alterations in villus structure; III, serious lymphocyte infiltration with alterations in villus structure; and IV, serious lymphocyte infiltration with alterations in villus structure and necrosis of mucosa tissue. Peritoneal lipid accumulation was measured in one histological section per fish using the software AxioVision 4.8.

Bacterial counts for the stomach and intestine were performed at the Laboratório de Fitoplâncton e Microoganismos Marinhos/IO - FURG. The samples were carefully removed from the $4 \%$ formalin solution, sectioned (stomach and proximal, mid and distal intestine), opened in previously autoclaved Petri dishes, and washed with $10 \mathrm{~mL}$ of MilliQ water. The solution was transferred to $40-\mathrm{mL}$ glass jars and sonicated (Cole-Parmer Instrument Co., Chicago, IL, USA) in three 10 -second pulses with a 10 -second interval between each pulse. One 1.0-mL aliquot was filtered through polycarbonate membrane filters (Nucleopore, Kent, UK, $0.2 \mu \mathrm{m}$ porosity) that had been previously darkened with 12\% Irgalan black. The filtrates were then stained with acridine orange $\left(1 \mu \mathrm{g} \mathrm{mL}^{-1}\right)$ (Hobbie et al. 1977). Bacteria were counted in 30 random fields using a Zeiss Axioplan epifluorescence microscope (Oberkochen, Germany) equipped with a blue filter (487709 - BP 450-490, FT 510, LT 520) and a Watec CCD (Watec Co., Yagamata, Japan) (0.0003 Lux). The Image Tool UT 3.0 software was used for counting.

\section{STATISTICAL ANALYSIS}

The results of water quality, growth performance, biometrical indices, body composition and peritoneal lipid accumulation were subjected to an analysis of variance (ANOVA), with a previous check of the analysis assumptions (normality by Shapiro-Wilks and variance homogeneity by Levene). A mathematical transformation was applied when the premises did not satisfy the analysis of variance assumptions. Two-way ANOVA was applied to the microbial counts to identify interactions between the enzyme level included and the bacterial populations in the different intestinal tract segments. The Tukey test (5\% of significance) was applied to identify significant differences from the means (Zar 1984).

\section{RESULTS}

\section{GROWTH PARAMETERS}

A significant difference $(P<0.05)$ was only observed for calcium retention. In contrast, no differences $(P>0.05)$ were observed in the other growth parameters analyzed (Table II).

\section{PROXIMAL MUSCLE COMPOSITION}

Significant differences $(P<0.05)$ in the bone $\mathrm{Ca}$ parameter (Table III) were found. The E100 and E150 treatments resulted in higher levels of bone $\mathrm{Ca}$ than did the control and E50 treatments.

\section{INTESTINAL HISTOLOGICAL ANALYSIS}

The semi-quantitative scores for intestinal lesions are listed in Table IV. In the control group, the fish showed lesions with scores of I, II, III and IV. Conversely, the fish in all of the treatments with enzyme inclusion only exhibited lesions scoring I (Fig. 1). For peritoneal lipid deposition, the fish from the control group showed significantly $(P<0.05)$ less lipid accumulation in the peritoneal area than the fish from all of the enzyme groups, and the values did not differ between these groups (Fig. 2).

\section{BACTERIAL COUNTS}

Four bacterial morphotypes were recognized: cocci $(\mathrm{Cc})$, vibrio $(\mathrm{Vb})$, bacilli $(\mathrm{Bc})$ and filamentous $(\mathrm{Fl})$.

Two-way ANOVA showed no interaction $(P>0.05)$ between the intestinal tract sections and treatments for any of the bacterial counts performed. 
TABLE II

Growth parameters of mullet $M$. liza juveniles fed with increasing levels of dietary exogenous enzyme complex in the soybean-meal based diets (E0: Control $-0 \mathrm{~g} \mathrm{ton}^{-1}$; E50: $50 \mathrm{~g} \mathrm{ton}^{-1}$; E100: $100 \mathrm{~g} \mathrm{ton}^{-1}$; E150: $150 \mathrm{~g} \mathrm{ton}^{-1}$; and E200: $\left.200 \mathrm{~g} \mathrm{ton}^{-1}\right)^{*}$.

\begin{tabular}{|c|c|c|c|c|c|}
\hline Parameters & E0 & E50 & E100 & E150 & E200 \\
\hline $\mathbf{A} \mathbf{W}_{\text {initial }}$ & $0.18 \pm 0.005$ & $0.18 \pm 0.005$ & $0.18 \pm 0.005$ & $0.18 \pm 0.005$ & $0.18 \pm 0.005$ \\
\hline $\mathbf{A W}_{\text {final }}$ & $1.17 \pm 0.10$ & $1.40 \pm 0.27$ & $1.25 \pm 0.22$ & $1.37 \pm 0.27$ & $1.22 \pm 0.09$ \\
\hline WG & $0.99 \pm 0.09$ & $1.22 \pm 0.27$ & $1.08 \pm 0.21$ & $1.19 \pm 0.28$ & $0.91 \pm 0.21$ \\
\hline SGR & $2.70 \pm 0.11$ & $2.93 \pm 0.29$ & $2.83 \pm 0.17$ & $2.94 \pm 0.28$ & $2.76 \pm 0.11$ \\
\hline FI & $3.01 \pm 0.25$ & $3.44 \pm 0.54$ & $3.17 \pm 0.45$ & $3.26 \pm 0.43$ & $3.32 \pm 0.49$ \\
\hline FCR & $3.11 \pm 0.41$ & $2.88 \pm 0.26$ & $3.06 \pm 0.30$ & $2.83 \pm 0.32$ & $3.04 \pm 0.15$ \\
\hline PI & $1.02 \pm 0.08$ & $1.13 \pm 0.21$ & $1.08 \pm 0.15$ & $1.11 \pm 0.15$ & $1.13 \pm 0.17$ \\
\hline PER & $0.96 \pm 0.12$ & $1.02 \pm 0.09$ & $0.93 \pm 0.10$ & $1.03 \pm 0.14$ & $0.89 \pm 0.08$ \\
\hline PhR & $4.41 \pm 0.82$ & $4.56 \pm 0.96$ & $3.61 \pm 0.78$ & $4.69 \pm 1.71$ & $3.70 \pm 0.31$ \\
\hline CaR & $7.07 \pm 0.36 b$ & $7.37 \pm 1.28 b$ & $10.23 \pm 0.62 \mathrm{ab}$ & $11.14 \pm 0.53 \mathrm{a}$ & $9.20 \pm 2.15 \mathrm{ab}$ \\
\hline Survival & $96.7 \pm 5.77$ & $95.0 \pm 5.0$ & $93.3 \pm 5.77$ & $96.7 \pm 2.89$ & $96.7 \pm 2.89$ \\
\hline \multicolumn{6}{|c|}{ Biometrical indexes } \\
\hline $\mathbf{K}$ & $1.26 \pm 0.04$ & $1.24 \pm 0.01$ & $1.14 \pm 0.21$ & $1.28 \pm 0.03$ & $1.22 \pm 0.02$ \\
\hline HSI & $1.48 \pm 0.40$ & $1.22 \pm 0.11$ & $1.26 \pm 0.13$ & $1.18 \pm 0.06$ & $1.25 \pm 0.064$ \\
\hline VSI & $14.61 \pm 4.37$ & $12.02 \pm 0.24$ & $13.95 \pm 2.75$ & $15.87 \pm 3.78$ & $12.11 \pm 0.62$ \\
\hline
\end{tabular}

*Values are means \pm SD of triplicates groups. Different letters indicates a significant difference $(\mathrm{P}<0.05)$. ns $=$ non-significant. AW, average weight; WG, weight gain; SGR, specific growth rate; FI, feed intake; FCR, feed conversion rate; PI, protein intake; PER, protein efficiency rate; $\mathrm{PhR}$, phosphorus retention; CaR, calcium retention; $\mathrm{K}$, condition factor; HSI, hepatic somatic index; and IVS, viscera somatic index.

TABLE III

Proximal muscle composition of mullet $\mathrm{M}$. liza juveniles fed increasing levels of dietary exogenous enzyme complex in the soybean-based diets (E0: Control $-0 \mathrm{~g}^{-1}{ }^{-1}$; E50: $50 \mathrm{~g} \mathrm{ton}^{-1}$; E100: $100 \mathrm{~g} \mathrm{ton}^{-1}$; E150: $150 \mathrm{~g} \mathrm{ton}^{-1}$; and E200: $200 \mathrm{~g}$ ton $\left.{ }^{-1}\right)^{*}$.

\begin{tabular}{|c|c|c|c|c|c|c|}
\hline \multirow{2}{*}{ Proximate composition } & \multirow[b]{2}{*}{ Initial } & \multicolumn{5}{|c|}{ Final } \\
\hline & & E0 & E50 & E100 & E150 & E200 \\
\hline Dry Matter & $21.45 \pm 0.60$ & $35.66 \pm 5.67$ & $33.60 \pm 2.18$ & $35.02 \pm 3.58$ & $39.97 \pm 6.14$ & $37.40 \pm 4.76$ \\
\hline Crude Protein & $13.47 \pm 0.91$ & $19.61 \pm 3.31$ & $18.39 \pm 1.12$ & $18.54 \pm 2.39$ & $20.38 \pm 2.89$ & $20.62 \pm 3.84$ \\
\hline Ether Extract & $5.55 \pm 2.81$ & $8.84 \pm 2.37$ & $9.61 \pm 1.52$ & $12.05 \pm 2.92$ & $11.02 \pm 1.75$ & $10.84 \pm 1.53$ \\
\hline Ashes & $4.01 \pm 0.07$ & $4.83 \pm 0.82$ & $4.62 \pm 0.54$ & $4.66 \pm 0.07$ & $5.37 \pm 0.63$ & $5.15 \pm 0.72$ \\
\hline Bone P & $2.56 \pm 0.88$ & $4.43 \pm 0,50$ & $4.98 \pm 0.97$ & $4.02 \pm 0.76$ & $4.32 \pm 1.37$ & $3.70 \pm 0.39$ \\
\hline Bone Ca & $6.42 \pm 1.21$ & $7.08 \pm 0.88 b$ & $7.24 \pm 1.16 b$ & $10.38 \pm 0.75 a$ & $11.22 \pm 0.52 \mathrm{a}$ & $8.95 \pm 1.96 \mathrm{ab}$ \\
\hline
\end{tabular}

*Values are means \pm SD of triplicates groups. Different letters indicate significant differences $(\mathrm{P}<0.05)$. ns $=$ non-significant.

TABLE IV

Intestinal lesions observed in mullet $M$. liza juveniles fed with increasing levels of dietary exogenous enzyme complex in the soybean-based diets (E0: Control - $0 \mathrm{~g}$ ton ${ }^{-}$ ${ }^{1}$; E50: $50 \mathrm{~g} \mathrm{ton}^{-1}$; E100: $100 \mathrm{~g}^{-1}{ }^{-1}$; E150: $150 \mathrm{~g} \mathrm{ton}^{-1}$; and E200: $\left.200 \mathrm{~g} \mathrm{ton}^{-1}\right)$.

\begin{tabular}{lccccc}
\hline \multirow{2}{*}{ Treatment } & \multirow{2}{*}{ Observations } & \multicolumn{5}{c}{ Score levels } \\
\cline { 2 - 5 } & & I & II & III & IV \\
\hline Control & $n=9$ & 1 & 3 & 2 & 3 \\
E50 & $n=9$ & 5 & 4 & & \\
E100 & $n=9$ & 9 & & & \\
E150 & $n=9$ & 9 & & & \\
E200 & $n=9$ & 9 & & & \\
\hline
\end{tabular}

However, the tract section counts exhibited a significant difference $(P<0.05)$ because the stomach had higher counts than the intestinal compartments for both the total bacterial count and all of the morphotypes analyzed. In addition, significant differences $(P<0.05)$ were observed among the treatments for the filamentous morphotype, which was found in higher abundance in the fish from the treatment E50 group compared with those from the E150 group (Table V). 

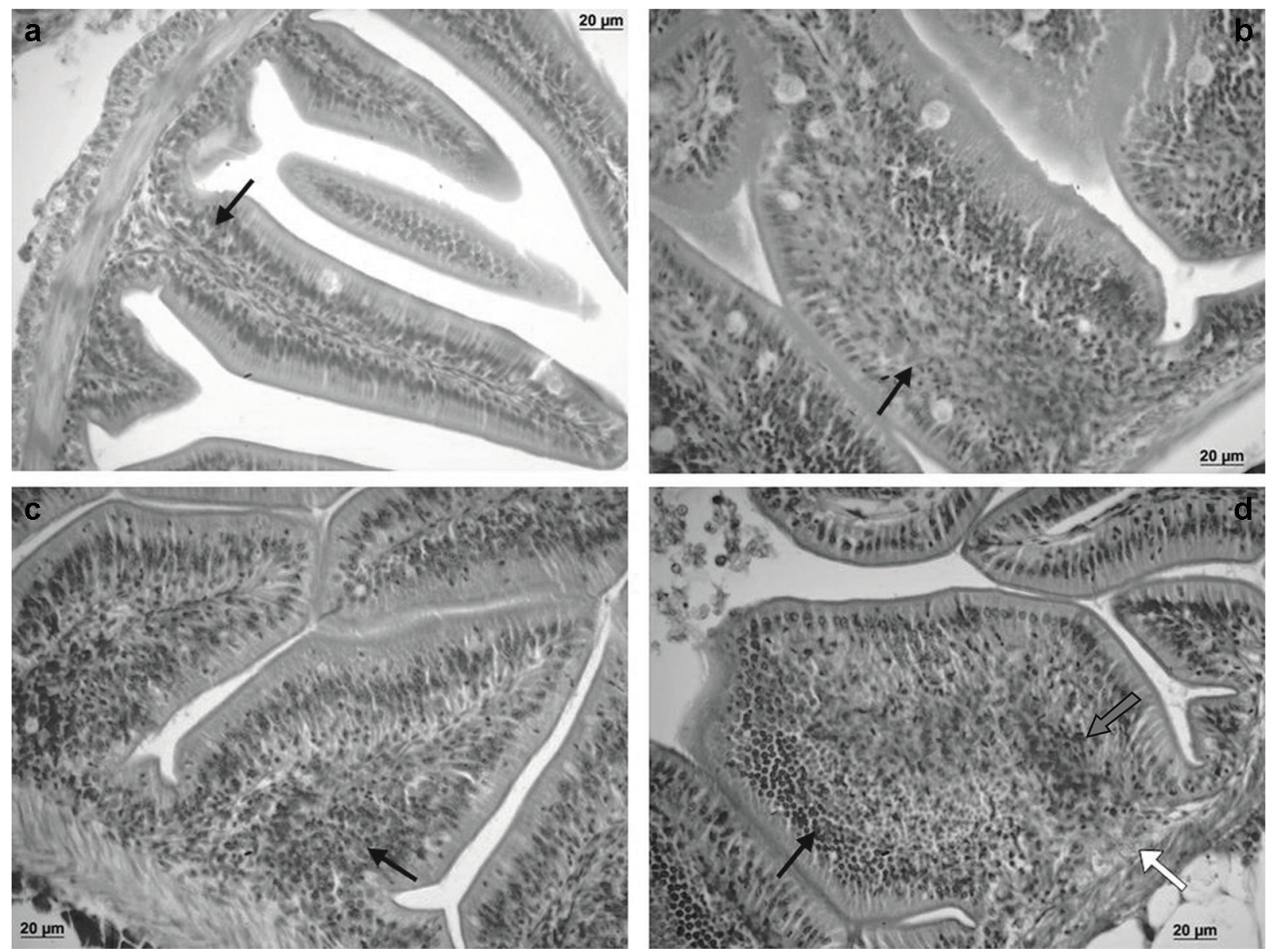

Figure 1 - Histology screening of intestinal folds of mullets juveniles fed experimental diets: shown are lymphocyte infiltration (black arrow), necrosis (white arrow), hemorrhagic lesions (grey arrow) and deformation of intestinal folds (B, C and D); a normal intestinal fold is shown in (A). Clockwise: A - score I; B - score II; C - score III; and D - score IV.

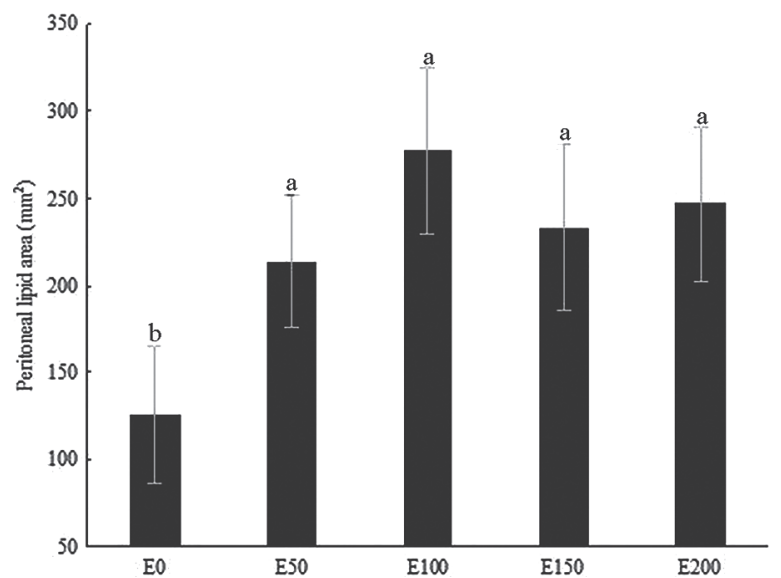

Figure 2 - Peritoneal lipid area of mullet juveniles fed experimental diets (E0: Control - $0 \mathrm{~g} \mathrm{ton}^{-1}$; E50: $50 \mathrm{~g} \mathrm{ton}^{-1}$, E100: $100 \mathrm{~g} \mathrm{ton}^{-1}$, E150: $150 \mathrm{~g}$ ton $^{-1}$, E200: and $\left.200 \mathrm{~g}_{\text {ton }^{-1}}\right)$. Different letters indicate significant differences $(P<0.05)$ between treatments.

\section{DISCUSSION}

The results of enzyme utilization in aquaculture are often contradictory and may be related to variables such as fish species, feeding habit, enzyme type and the mixture and plant source utilized. Here, no significant differences were observed in animal performance with the inclusion of an enzyme complex, similar to results found in the literature (Stone et al. 2003, Ogunkoya et al. 2006, Farhangi and Carter 2007, Yigit and Olmez 2011, Dalsgaard et al. 2012).

A higher lipid deposition was observed in the peritoneal area of the fish fed the enzyme cocktail compared with those fish fed a diet lacking the enzyme mixture. Two possible explanations are 
TABLE V

Bacterial counts in the gastrointestinal tract of $M$. liza juveniles fed increasing levels of dietary exogenous enzyme complex in the soybean-based diets (E0: Control - $0 \mathrm{~g} \mathrm{ton}^{-1}$; E50: $50 \mathrm{~g} \mathrm{ton}^{-1}$; E100: $100 \mathrm{~g} \mathrm{ton}^{-1}$; E150: $150 \mathrm{~g} \mathrm{ton}^{-1}$; and E200: $200 \mathrm{~g} \mathrm{ton}^{-1}$ ). All of the values units are in $\mathrm{x10}^{-7} \mathrm{org} \mathrm{m}^{-1 *}$.

\begin{tabular}{lcccc}
\hline Section & Total Bacteria & Cocci & Vibrio & Bacilli \\
\hline Stomach & $20.67 \pm 6.60 \mathrm{a}$ & $5.55 \pm 1.95 \mathrm{a}$ & $9.77 \pm 3.07 \mathrm{a}$ & $1.63 \pm 0.42 \mathrm{a}$ \\
Proximal I. & $8.48 \pm 4.22 \mathrm{~b}$ & $2.46 \pm 1.22 \mathrm{~b}$ & $4.03 \pm 1.89 \mathrm{~b}$ & $1.11 \pm 0.29 \mathrm{~b}$ \\
Mid I. & $10.65 \pm 6.26 \mathrm{~b}$ & $3.18 \pm 1.58 \mathrm{~b}$ & $5.24 \pm 3.26 \mathrm{~b}$ & $1.55 \pm 0.40 \mathrm{~b}$ \\
Distal I. & $9.68 \pm 4.64 \mathrm{~b}$ & $2.92 \pm 1.31 \mathrm{~b}$ & $4.73 \pm 2.55 \mathrm{~b}$ & $0.94 \pm 0.24 \mathrm{~b}$ \\
\hline Treatments & & & & \\
\hline E0 & $13.22 \pm 8.95 \mathrm{~ns}$ & $3.50 \pm 2.29 \mathrm{~ns}$ & $6.44 \pm 4.40 \mathrm{~ns}$ & $2.92 \pm 2.03 \mathrm{~ns}$ \\
E50 & $13.77 \pm 8.05 \mathrm{~ns}$ & $3.79 \pm 1.83 \mathrm{~ns}$ & $6.33 \pm 3.80 \mathrm{~ns}$ & $3.10 \pm 2.12 \mathrm{~ns}$ \\
E100 & $13.55 \pm 8.68 \mathrm{~ns}$ & $4.23 \pm 2.45 \mathrm{~ns}$ & $6.44 \pm 4.12 \mathrm{~ns}$ & $2.62 \pm 2.01 \mathrm{~ns}$ \\
E150 & $9.07 \pm 4.28 \mathrm{~ns}$ & $2.62 \pm 1.03 \mathrm{~ns}$ & $4.44 \pm 2.13 \mathrm{~ns}$ & $1.80 \pm 1.11 \mathrm{~ns}$ \\
E200 & $12.26 \pm 5.44 \mathrm{~ns}$ & $3.50 \pm 1.64 \mathrm{~ns}$ & $6.08 \pm 2.72 \mathrm{~ns}$ & $2.42 \pm 1.12 \mathrm{~ns}$ \\
\hline
\end{tabular}

*Values are means $\pm \mathrm{SD}$ of triplicates groups. Different letters indicate significant difference $(\mathrm{P}<0.05) . \mathrm{ns}=$ non-significant.

presented; first, an increase in lipid digestibility in those fish fed diets with enzyme supplementation may have contributed to the higher lipid deposition observed. Dalsgaard et al. (2012) observed similar result in rainbow trout fed a high inclusion of soybean meal supplemented with $\beta$-glucanase. The second possible explanation for the higher lipid deposition could be the result of higher amounts of substrates released by enzyme degradation, which are prone to fermentation by microorganisms present in the gastrointestinal tract (Castillo and Gatlin 2014, Sinha et al. 2011). According to Tocher and Glencross (2015), lipid deposition in the peritoneal cavity is indicative of excess energy in the diet and can result in adverse representations of final weight, since protein content in the body is the principal aim of the animal production. Thus, care is necessary when developing feed formulations with enzyme supplementations, especially in regards to growth output.

Some reviews have highlighted the effects of the phytase enzyme on fish nutrition, with most reporting the augmentation of phytate-phosphorus absorption and bound minerals, such as calcium, as well as the enhancement of growth performance
(Cao et al. 2007, Singh and Satyanarayana 2014, Dersjant-Li et al. 2014). In the present study, intermediary levels of enzyme complex (100 and $150 \mathrm{~g} \mathrm{ton}^{-1}$ ) in the diet resulted in elevated calcium bone concentration and calcium retention in fish. A similar pattern was not observed for phosphorus. Meanwhile, bone ash and growth performance represent important parameters utilized in validating phytase efficacy (Dersjant-Li et al. 2014); the present study lacks such results, despite using appropriate levels of phytase $(500-2000$ FTU $\mathrm{kg}^{-1}$ ) (Cao et al. 2007). This may be a result of the available-P level in the diet could too limited to reflect in the bone composition and performance; and/or an inadequate $\mathrm{Ca}: \mathrm{P}$ relation in the ration for this fish species, as calcium plays an important role in phytase activity (Cao et al. 2007).

The fiber fraction of soybean meal is approximately $18 \%$ and is represented by cellulose, hemicellulose and pectin. Pectin is the most common of these and is termed non-starch polysaccharide. Non-starch polysaccharide is recognized as an antinutritional factor that impairs fish digestion by increasing the digesta viscosity and gut physiology (Hossain et al. 2001, Leenhouwers et al. 2006, 
2007, Biernasiak 2011, Burssens et al. 2011). Soybean meal diets are known to increase the infiltration of inflammatory leukocytes into the intestinal mucosa, and to shorten the mucosal folds in salmonid fish species (Krogdahl et al. 2003, 2010, Ostaszewska et al. 2005, Bakke-McKellep et al. 2007), which was described by Baeverfjord and Krogdahl (1996) as non-infectious subacute enteritis.

Ramos et al. (2015a) observed intestinal lesions in mullets fed citrus pectin, similar to the lesions found in salmonids fed soybean meal (Baeverfjord and Krogdhal 1996, Krogdahl et al. 2003, Bakke-McKellep et al. 2007). In the present study, some fish in the control treatment (no enzyme supplementation) manifested moderate to serious infiltration of inflammatory cells along with alterations of villus morphology and, in some cases, necrosis of intestinal tissue. Conversely, the fish in all of the enzyme-fed groups showed only slight cell infiltration, which is normal in healthy individuals. However, fish performance was not impaired during the 75 days of the experiment, with final weight 6.5 times higher on average than the initial weight. For more prolonged periods, this supplementation could be more dangerous, as noted by de Francesco et al. (2004) for rainbow trout under a plant-based feed regime for 157 days. The enzymes present in the cocktail, most of which were carbohydrases, included enzymes that hydrolyze non-starch polysaccharides (xylanases, pectinases, $\beta$-glycosidases), which may have dampened the effects observed in the intestinal tissue of the fish fed the with control soybean-base diet.

The mullets in the present study exhibited distribution of bacteria along the gastrointestinal tract similar to previous works (Ramos et al. 2015a, 2015b). Bacteria were more abundant in the stomach than in intestinal sections; the authors identify that this microbial pattern could indicate that M. liza utilizes the bacterial biomass for its own growth, similar to ruminant animals, whose nutrition relies mainly on bacterial-fermentable products and the microbial biomass present in the forestomach (Hill et al. 2008). Further studies evaluating the effect of enzyme inclusion associated with antibiotics in mullet diets could help to clarify such issues.

The gastrointestinal microbial community in fish plays an important role in nutrition but is neglected in most studies regarding feed enzymes. Even with respect to monogastric nutrition (e.g., poultry and swine), which already incorporates feed enzymes, few studies have focused on the effects of enzyme inclusion on microbiota in nutrition (Bedford and Cowieson 2012). Although some recent works have investigated the addition of enzymes, only two studies have evaluated their effect upon the microbial community from the intestinal tract. Zhou et al. (2013) evaluated the effect of dietary cellulase inclusion on intestinal microbiota and the growth of grass carp; the results suggested that cellulase altered the bacterial species and density in the digestive tract. Adeoyde et al. (2016) investigated the inclusion of phytases, proteases and carbohydrases in plant-based diets for the Nile tilápia Oreochromis niloticus and observed modifications in intestinal bacterial community in fish fed with carbohydrases.

Here, microbial counts showed minimal difference between the filamentous groups E50 and E150 enzyme treatments, with the former showing higher counts than the latter. A group of ubiquitous filamentous bacteria, referred to as segmented filamentous bacteria (SFB), inhabit the gut of humans and others animals including invertebrates, SFB are associated with benefits to the health of the host by enhancing immunological defenses, innate responses, and humoral and cell-mediated responses (Ericsson et al. 2014). However, SFB have only found been found in two species of freshwater fishes: the common carp and rainbow trout. The presence of a large number of SFB may cause infectious diarrhea, a pathological status know as Rainbow Trout Gastroenteritis (Klaasen et al. 1993, Urdaci et al. 2001, Del-Pozo et al. 2010). 
No sign of this disease was observed in any fish in the present study. Therefore, it is recommended that further studies be performed using molecular tools, such as fluorescent in situ hybridization (FISH) and 16S rRNA gene analysis, to determine whether the same filamentous groups are present in the $M$. liza gut, their role in fish welfare, and how enzyme feeding may affect these bacteria.

\section{CONCLUSIONS}

Under the conditions of the present experiment, supplementation with the enzyme complex did not improve animal performance or influence biometrical indices. Enzyme supplementation did elevate bone calcium content, as reflected by the high calcium retention parameter, and the lipid content in the peritoneal cavity. The present study showed that enzyme supplementation, even at a low level, reduced the intestinal damage caused by the soybean meal-based diet. Therefore, it is recommended that when plant sources are used in feed for this species, particularly when pectin polysaccharides are present, $50 \mathrm{~g}^{\text {ton }}{ }^{-1}$ of enzyme complex should be added to prevent intestinal damage.

\section{ACKNOWLEDGMENTS}

L.R.V. Ramos is supported by Coordenação de Aperfeiçoamento de Pessoal de Nível Superior (CAPES - Brazil). Part of this study was supported by a grant from the Conselho Nacional de Desenvolvimento Científico e Tecnológico (CNPQ UNIVERSAL, process number 471376/2012-4) given to Tesser, M.B. and by CAPES (Ciências do Mar). Romano L.A., Abreu P.C. and Tesser M.B. are research fellows from Brazilian agency CNPq. We also thank Adisseo Brasil for providing the enzyme complex and support. The authors declare have not conflict of interest.

\section{REFERENCES}

ADEOYDE AA, JARAMILLO-TORRES A, FOX SW, MERRIFIELD DL AND DAVIES SJ. 2016.
Supplementation of formulated diets for tilapia (Oreochromis niloticus) with selected exogenous enzyme: Overall performance and effects on intestinal histology and microbiota. Anim Feed Sci Tech 215: 133-143.

AI Q, MAI K, ZHANG W, XU W, TAN B, ZHANG C AND LI H. 2007. Effects of exogenous enzymes (phytase, nonstarch polysaccharides enzyme) in diets on growth, feed utilization, nitrogen and phosphorus excretion of Japanese seabass, Lateolabrax japonicus. Comp Biochem Physiol Part A 147: 502-508.

ASSOCIATION OF OFFICIAL ANALITYCAL CHEMISTS. 1999. Official methods of analysis of the AOAC. Washington: AOAC International. $16^{\text {th }}$ ed, $1141 \mathrm{p}$.

BAEVERFJORD G AND KROGDAHL À. 1996. Development and regression of soybean meal induced enteritis in Atlantic salmon, Salmo salar L., distal intestine: comparison with the intestine of fasted fish. J Fish Dis 19: 375-387.

BAKKE-MCKELLEP AM, PENN MH, SALAS PM, REFSTIE S, SPERSTAD S, LANDSVERK T, RINGO E AND KROGDAHL A. 2007. Effects of dietary soybean meal, inulin and oxytetracycline on intestinal microbiota and epithelial cell stress, apoptosis and proliferation in the teleost Atlantic salmon (Salmo salar L.). Brit J Nutr 97: 699-713.

BARLETTA A. 2010. Current market and expected developments. In: Bedford MR and Partridge GG (Eds), Enzymes in farm animal nutrition, CABI International, Oxfordshire, UK, p. 1-11.

BEDFORD MR AND COWIESON AJ. 2012. Exogenous enzyme and their effects on intestinal microbiology. Anim Feed Sci Tech 173: 76-85.

BIERNASIAK J, SLIZEWSKA K AND LIBUDZISZ Z. 2011. Feeds with probiotics in animal's nutrition. In: El-Shamy HA (Ed), Soybean \& Nutrition, In Tech, Croatia, p. 181200.

BURSSENS S, PERTRY I, NGUDI DD, KUO YH, VAN MONTAGU M AND LAMBEIN F. 2011. Soya, Human Nutrition and Health. In: El-Shamy HA (Ed), Soybean \& Nutrition, In Tech, Croatia, p. 157-189.

CAO L, WEIMIN W, YANG C, YANG Y, DIANA J, YAKUPITIYAGE A, LUO Z AND LI D. 2007. Application of microbial phytase in fish feed. Enzyme Microb Tech 40: 497-507.

CARTER CG, HOULIHAN DF, BUCHANAN B AND MITCHELL AI. 1994. Growth and feed utilization efficiencies of seawater Atlantic salmon, Salmo salar L., fed a diet containing supplementary enzymes. Aquac Res 25: $37-46$

CARVALHO CVA, BIANCHINI A, TESSER MB AND SAMPAIO LA. 2010. The effect of protein levels on growth, postprandial excretion and tryptic activity of juvenile mullet Mugil platanus (Günther). Aquac Res 41: 511-518. 
CASTILLO S AND GATLIN DM. 2014. Dietary supplementation of exogenous carbohydrase enzymes in fish nutrition: a review. Aquaculture 435: 286-292.

DALSGAARD J, VELHAC V, HJERMITSLEV NH, EKMANN KS, FISCHER M, KLAUSEN M AND PEDERSEN PB. 2012. Effects of exogenous enzyme on apparent nutrient digestibility in rainbow trout (Oncorhynchus mykiss) fed diets with high inclusion of plant-based protein. Anim Feed Sci Tech 171: 181-191.

DE FRANCESCO M, PARISI G, MÉDALE F, LUPI P, KAUSHIK J AND POLI BM. 2004. Effect of longterm feeding with a plant protein mixture based diet on growth and body/fillet quality traits of large rainbow trout (Oncorhynchus mykiss). Aquaculture 236: 413-429.

DEL-POZO J, TUMBULL J, FERGUSON H AND CRUMLISH M. 2010. A comparative molecular study of the presence of "Candidatus arthromitus" in the digestive system of rainbow trout, Oncorhynchus mykiss (Walbaum), healthy and affected with rainbow trout gastroenteritis. J Fish Dis 33: 241-250.

DERSJANT-LI Y, AWATI A, SCHULZE H AND PARTRIDGE G. 2014. Phytase in non-ruminant animal nutrition: a critical review on phytase activities in the gastrointestinal tract and influencing factors. J Sci Food Agr 95: 878-896.

ERICSSON AC, HAGAN CE, DAVIS DJ AND FRANKLIN CL. 2014. Segmented filamentous bacteria: commensal microbes with potential effects on research. Comparative Med 64: 90-98.

FAO. 2006. Cultured Aquatic Species Information Programme: Mugil cephalus (Linnaeus, 1758). In: Food and Agriculture Organization of the United Nations - Fisheries and Aquaculture Department. Rome, Italy.

FARHANGI M AND CARTER CG. 2007. Effect of enzyme supplementation to dehulled lupin-based diets on growth, feed efficiency, nutrient digestibility and carcass composition of rainbow trout, Oncorhynchus mykiss (Walbaum). Aquac Res 38: 1274-1282.

FRANCIS G, MAKKAR HPS AND BECKER K. 2001. Antinutritional factors present in plant-derived alternate fish feed ingredients and their effects in fish. Aquaculture 199: 197-227.

GATLIN ET AL. 2007. Expanding the utilization of sustainable plant products in aquafeeeds: a review. Aquac Res 318: 551-579.

GARLING DL AND WILSON RP. 1976. Optimum dietary protein to energy ratio for channel catfish fingerlings, Ictalarus punctatus. J Nutr 106: 1268-1375.

GHOMI MR, SHAHRIARI R, LANGROUDI F, NIKOO M AND VON ELERT E. 2012. Effects of exogenous dietary enzyme on growth, body composition, and fatty acid profiles of cultured great sturgeon Huso huso fingerlings. Aquac Int 20: 249-254.

GONZÁLEZ CASTRO M, ABACHIAN V AND PERROTTA RG. 2009. Age and growth of the striped mullet, Mugil platanus (Actinopterygii, Mugilidae), in a southwest Atlantic coastal lagoon $\left(37^{\circ} 32^{\prime} \mathrm{S}-57^{\circ} 19^{\prime} \mathrm{W}\right)$ : a proposal for a life-history model. J Appl Ichthyol 25: 61-66.

HARDY RW. 2010. Utilization of plant proteins in fish diets: effects of global demand and supplies of fishmeal. Aquac Res 41: 770-776.

HILL RW, WYSE GA AND ANDERSON M. 2008. Animal Physiology. $2^{\text {nd }}$ ed., Sinauer Associates, 770 p.

HOBBIE JE, DALEY RR AND JASPER S. 1977. Use of nucleopore filters for counting bacteria by fluorescence microscopy. Appl Environ Microb 33: 1225-1228.

HOSSAIN MA, FOCKEN U AND BECKER K. 2001. Galactomannan-rich endosperm of Sesbania (Sesbania aculeata) seeds responsible for retardation of growth and feed utilization in common carp Cyprinus carpio L. Aquaculture 203: 121-132.

KLAASEN HLBM, KOOPMAN JP, VAN DEN BRINK ME, BAKKER MH, POELMA FGJ AND BEYNEN AC. 1993. Intestinal, segmented, filamentous bacteria in a wide range of vertebrate species. Lab Anim 27: 141-150.

KROGDAHL A, BAKKE-MCKELLEP AM AND BAEVERFJORD G. 2003. Effects of graded levels of standard soybean meal on intestinal structure, mucosal enzyme activities, and pancreatic response in Atlantic salmon (Salmo salar L.). Aquac Nut 9: 361-371.

KROGDAHL A, PENN M, THORSEN J, REFSTIE S AND BAKKE AM. 2010. Important antinutrients in plant feedstuffs for aquaculture: an update on recent findings regarding responses in salmonids. Aquac Res 41: 333-344.

LEENHOUWERS JI, ADJEI-BOATENG D, VERRETH JAJ AND SCHRAMA JW. 2006. Digesta viscosity, nutrient digestibility and organ weights in African catfish (Clarias gariepinus) fed diets supplemented with different levels of a soluble non-starch polysaccharide. Aquac Nut 12: 111116.

LEENHOUWERS JI, ORTEGA RC, VERRETH JAJ AND SCHRAMA JW. 2007. Digesta characteristics in relation to nutrient digestibility and mineral absorption in Nile tilapia (Oreochromis niloticus L.) fed cereal grains of increasing viscosity. Aquaculture 273: 556-565.

LIN S, MAI K AND TAN B. 2007. Effect of exogenous enzyme supplementation in diets on growth and feed utilization in tilapia, Oreochromis niloticus x O. aureus. Aquac Res 38: 1645-1653.

MIRANDA-FILHO K, TESSER MB, SAMPAIO LA AND GODINHO HM. 2010. Tainha. In: Baldisseroto B and Gomes LC (Eds), Espécies nativas para a piscicultura no Brasil, Editora UFSM, Santa Maria, Brasil, p. 541-552.

OGUNKOYA AE, PAGE GI, ADEWOLU MA AND BUREAU DP. 2006. Dietary incorporation of soybean meal and exogenous enzyme cocktail can affect physical characteristics of faecal material egested by rainbow trout (Oncorhynchus mykiss). Aquaculture 245: 466-475.

OLIVEIRA IR AND SOARES LSH. 1996. Alimentação da tainha Mugil platanus GÜNTHER, 1880 (PISCES: 
MUGILIDAE) da região estuarino-lagunar de Cananéia, São Paulo, Brasil. B Ins Pesca 23: 95-104.

OSTASZEWSKA T, DABROWSKI K, PALACIOS ME, OLEJNICZAK M AND WIECZOREK M. 2005. Growth and morphological changes in the digestive tract of rainbow trout (Oncorhynchus mykiss) and pacu (Piaractus mesopotamicus) due to casein replacement with soybean protein. Aquaculture 245: 273-286.

RAMOS LRV, MONSERRAT JM, ROMANO LA, SAMPAIO LA, ABREU PC AND TESSER MB. 2015a. Effects of supplementing the diets of Mugil liza Valenciennes, 1836 juvenile with citrus pectin. J Appl Ichthyol 31: 362-369.

RAMOS LRV, ROMANO LA, MONSERRAT JM, ABREU PC, VERDE PE AND TESSER MB. 2015b. Biological responses in mullet Mugil liza juveniles fed with guar gum supplemented diets. Anim Feed Sci Tech 205: 98-106.

SILVA DJ AND QUEIROZ AC. 2009. Análise de Alimentos: métodos químicos e biológicos. $3^{\mathrm{a}}$ ed., Viçosa: UFV, 235 p.

SINGH B AND SATYANARAYANA T. 2014. Fungal phytases: characteristics and amelioration of nutritional quality and growth of non-ruminants. J Anim Physiol An N 99: 646-660.

SINHA AK, KUMAR V, MAKKAR HPS, DE BOECK G AND BECKER K. 2011. Non-starch polysaccharides and their role in fish nutrition - A review. Food Chem 127: 1409-1426.

Stone DAJ, Allan GI and Anderson AJ. 2003. Carbohydrate utilization by juvenile silver perch, Bidyanus bidyanus (Mitchell). IV. Can dietary enzymes increase digestible energy from wheat starch, wheat and dehulled lupin? Aquac Res 34: 135-147.

UNESCO 1983. Chemical methods for use in marine environmental monitoring. Intergovernmental Oceanographic Commission, Paris, France. Manual and Guides, 53 p.
TOCHER DR AND GLENCROSS BD. 2015. Lipids and Fatty Acids. In Lee, C-S, Lin C, Gatlin DM and Webster CD (Eds), Dietary Nutrients, Additives and Fish Health. Wiley Blackwell, p. 47-94.

URDACI MC, REGNAULT B AND GRIMONT PAD. 2001. Identification by in situ hybridization of segmented filamentous bacteria in the intestine of diarrheic rainbow trout (Oncorhynchus mykiss). Res Microbiol 152: 67-73.

YIGIT NO AND OLMEZ M. 2010. Effects of cellulase addition to canola meal in tilapia (Orereochromis niloticus L.) diets. Aquac Nut 17: e494-e500.

YILDIRIM YB AND TURAN F. 2010. Effect of exogenous enzyme supplementation in diets on growth and feed utilization in African catfish, Clarias gariepinus. J Anim Vet Adv 9: 327-331.

ZAMORA-SILLERO J, RAMOS LRV, ROMANO LA, MONSERRAT JM AND TESSER MB. 2013. Effect of dietary dextrin levels on the growth performance, blood chemistry, body composition, hepatic triglycerides and glycogen of lebranche mullet juveniles (Mugil liza Valenciennes 1836, Mugilidae). J Appl Ichthyol 29: $1342-$ 1347.

ZAMINI AA, KANANI HG, ESMAEILI AA, RAMEZANI S AND ZORIEZAHRA SJ. 2014. Effects of two dietary exogenous multi-enzyme supplementation, Natuzyme ${ }^{\mathbb{B}}$ and beta-mannanase $\left(\right.$ Hemicell $\left.{ }^{\circledR}\right)$, on growth and blood parameters of Caspian salmon (Salmo trutta caspius). Comp Clin Pathol 23: 187-192.

Zar JH. 1984. Biostatical analysis, $2^{\text {nd }}$ ed., Prentice Hall, New Jersey, $960 \mathrm{p}$.

ZHOU Y, YUAN X, LIANG X-F, FANG L, LI J, GUO X, BAI XAND HE S. 2013. Enhancement of growth and intestinal flora in grass carp: The effect of exogenous cellulase. Aquaculture 416-417: 1-7. 
